\title{
Fogazati rendellenességek kezelési szükségletének tárgyilagos felmérése a Dental Aesthetic Index segítségével
}

\author{
Silvia Izabella Pop dr. ${ }^{1}$ - Mártha I. Krisztina dr. ${ }^{1}$ - Csibi Réka dr. ${ }^{2}$ \\ Mariana Păcurar dr. ${ }^{1}$. Ciotloș Minodora dr. ${ }^{2}$. Dana Cristina Bratu dr. ${ }^{3}$ \\ Marosvásárhelyi Orvosi és Gyógyszerészeti Egyetem, ${ }^{1}$ Fogorvosi Kar, Fogszabályozás Tanszék, \\ ${ }^{2}$ Fogorvosi Kar, Marosvásárhely, Románia \\ ${ }^{3}$ Faculty of Dental Medicine, Victor Babes University of Medicine and Pharmacy, Timisoara, Romania
}

\begin{abstract}
Bevezetés és célkitüzés: Egy marosvásárhelyi felnőtt pácienscsoport fogazati rendellenességeinek, ezek előfordulási arányának és súlyossági fokának életkor és nem szerinti felmérése.

Módszer: Hatvannégy, véletlenszerúen kiválasztott pácienst életkor és nem szerint osztályoztunk. A fogazati rendellenességekre jellemző, tíz fogíven belüli elváltozást (hiányzó fogak, hézagok, torlódások stb.) értékeltünk ki minden páciens tanulmányi mintáján. A Dental Aesthetic Index (DAI) szerinti regressziós egyenlettel meghatároztuk minden eset DAI-értékét és a rendellenesség súlyossági fokát.

Eredmények: A DAI-érték átlaga 38 volt; 18-79 közötti értékeket találtunk, ami azt mutatja, hogy a vizsgált egyének esetében elengedhetetlen a fogszabályozás. Nem találtunk statisztikailag szignifikáns különbséget a nemek, az életkor és a kezelés szükségszerúsége között.

Köpetkeztetés: A vizsgált csoport több mint 2/5-ének esetében szükségszerú a fogszabályozás, ha a DAI-értéket használjuk.

Orv Hetil. 2018; 159(9): 352-356.
\end{abstract}

Kulcsszavak: Dental Aesthetic Index, a kezelés szükségszerüsége, fogszabályozás

\section{Objective evaluation of orthodontic treatment need with Dental Aesthetic Index}

Introduction and aim: To evaluate the frequency and severity of the malocclusions and treatment need in a group of adult patients in Târgu-Mureș, dividing them up according to age and gender.

Method: Sixty-four, randomly selected patients were divided up according to age and gender. Ten occlusal traits related to dentofacial anomalies according to missing teeth, spacing, crowding and occlusion were used to evaluate the malocclusions on each of their study cast. The Dental Aesthetic Index (DAI) regression equation was used to obtain the DAI score that defines severity.

Results: The average DAI score was 38 with a range of 18-79, showing that the majority of patients needed mandatory orthodontic treatment. No statistically significant difference was found between gender, age groups and need for treatment.

Conclusion: More than two-fifths of the examined patients have a mandatory need for orthodontic treatment if the DAI scores are the main screening tool.

Keywords: Dental Aesthetic Index, treatment needs, orthodontics

Pop SI, Mártha IK, Csibi R, Păcurar M, Minodora C, Bratu DC. [Objective evaluation of orthodontic treatment need with Dental Aesthetic Index]. Orv Hetil. 2018; 159(9): 352-356.

(Beérkezett: 2017. szeptember 22.; elfogadva: 2017. október 26.) 


\section{Rövidítés}

DAI $=($ Dental Aesthetic Index $)$ fogászati esztétikai index

A Dental Aesthetic Index (fogászati esztétikai index, DAI) a statikus okklúzió esztétikai felmérését szolgáló mutató, amely pontos és értékelhető információkat szolgáltat a fogívek láthatóságáról, illetve a kezelés szükségszerűségéről. Matematikai összefüggést állít fel egy eset klinikai és esztétikai ismérvei között, s az értékkártya szerint kiszámítható egyéni érték [1] alapján megállapítható a rendellenesség súlyossági foka és ezen alapuló kezelési szükségszerüsége [2]. A DAI-t elsőként egy 200 alany okklúzióját ábrázoló fényképek [1] kiértékelésére alapuló amerikai tanulmány írja le, és a dentális esztétika közvélemény szerinti értékelésén alapszik [3]. A szóban forgó fényképeket 1337 [1, 3], 15-18 év közötti New York-i egyetemista tanulmányi modelljét ábrázoló fénykép közül véletlenszerüen válogatták ki (Ast és mtsai, 1965). Egy nemzetközi bírálóbizottság véleménye alapján a foobb okklúziós jellemvonásokat regressziós egyenlet segítségével matematikai értékké alakították át, és megszületett a DAI-mutatórendszer [3]. Különböző fogazati és faciális rendellenességekhez tartozó tíz okkluzális jellemvonás (hiányzó fogak, hézagok, torlódás stb.) alapján értékeket állapítottak meg, és ezek szerint értékelték a vizsgálatnak alávetett eseteket [4-6].

Ezek alapján a DAI-mutatórendszer a következőket tartalmazza:

1. látható hiányzó fogak (metszők, szemfogak, kisőrlők);

2. torlódás a fogív elülső szegmentumában;

3. hézagok/rések a frontális régióban;

4. diastema;

5. a felső fogív frontális torlódása;

6. az alsó fogív frontális torlódása

7. maxillaris overjet;

8. mandibularis overjet;

9. nyitott harapás;

10. az őrlők sagittalis relációja.

A DAI megmutatja ugyanakkor a rendellenesség súlyossági fokát is. Amennyiben a mutató értéke kisebb 25 nél, a harapási eltérés enyhe vagy akár hiányzik, és ilyen esetben a kezelés elengedhető. Ha a mutató értéke 26 és 30 között mozog, a harapási rendellenesség felismerhető, és a kezelés szükséges. Súlyos eltérésekről 31-35 közötti érték esetén beszélünk, és a kezelés szükségessége fokozott, míg 36 fölötti érték esetén a rendellenesség olyannyira súlyos, hogy a terápia kötelező $[2,4]$.

\section{Célkitüzés}

Tanulmányunk elsődleges célja egy marosvásárhelyi magánrendelő felnőtt betegeinek, az itt előforduló fogászati rendellenességek gyakoriságának, illetve ezek kezelési szükségletének felmérése volt. Másodsorban a kezelési szükségszerüség nemek és életkor szerinti eloszlását is vizsgálni szándékoztuk.

\section{Anyag és módszer}

Ezen retrospektív tanulmány során 102 felnőtt pácienst (életkoruk 16 és 54 év közötti volt) vizsgáltunk, akik a vizsgálat megkezdése előtti 20 hónapban felkeresték Natural Smile Dental Clinic nevú rendelőnket. Véletlenszerüen az adott beteganyagból 64 pácienst szelektáltunk, tanulmányi mintáikat sorszámoztuk és értékeltük. A kiválasztott eseteket nem és életkor szerint külön csoportokba soroltuk. A klinikai vizsgálat elvégzése után fényképeket készítettünk minden esetről, a DAI-mutatórendszer fellelhető okklúziós jellemvonásait értékeltük, és a regressziós analízis alapján minden esetben meghatároztuk az egyén DAI-mutatóját.

A regressziós egyenletben felhasznált értékek a tíz alapérték kerekítéséból származtak, mindegyik értéket felszoroztuk a regressziós együtthatóval. Az így kapott értékeket összeadtuk, majd a végösszeghez hozzáadva az állandót $(\mathrm{n}=13)$, megkaptuk minden egyén DAI-mutatóját (1. táblázat). Az így kapott értékek alapján minden esetet besoroltunk egy súlyossági kategóriába (2. táblázat).

Az adatokat Microsoft Excel 2010 programban összesítettük és dolgoztuk fel. A khí-négyzet-próba segítségével az életkorok szerinti elosztás és a kezelési szükségszerüség statisztikai feldolgozását végeztük, a Spearman-féle

1. táblázat | DAI-értékkártya

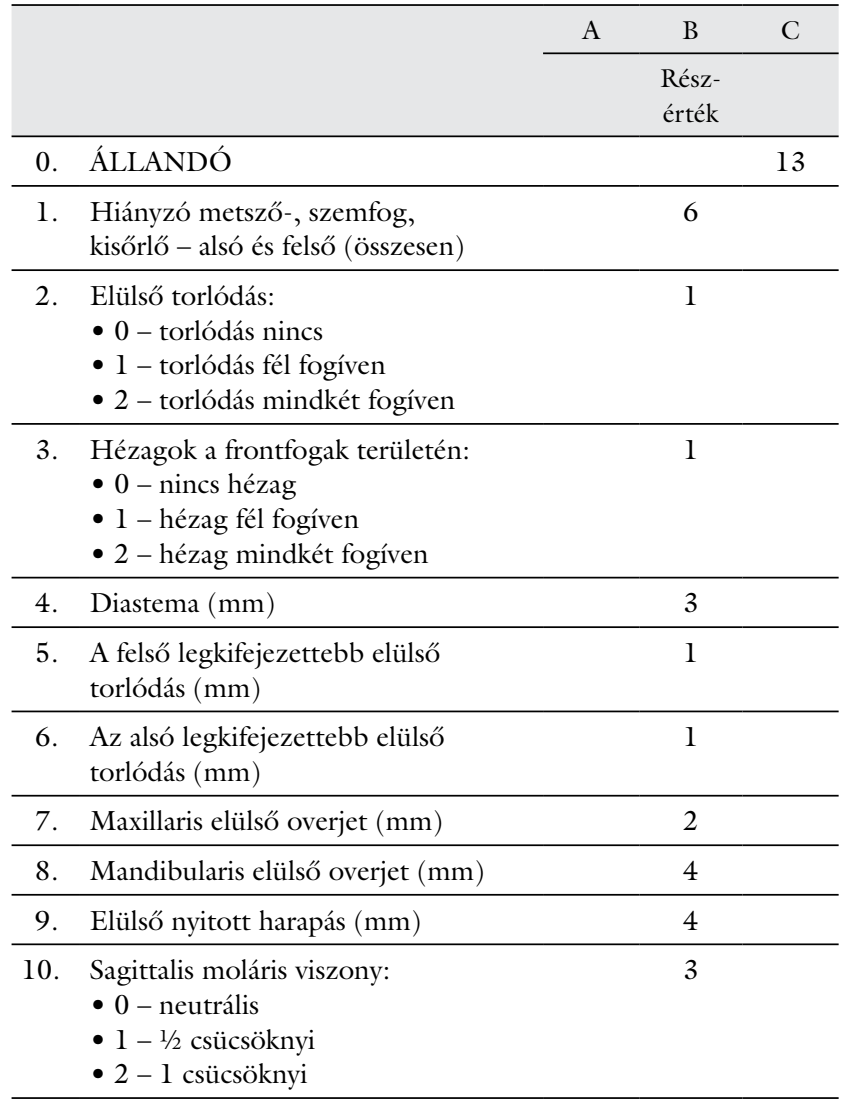

$\mathrm{A}=$ mért értékek; $\mathrm{B}=$ részérték; $\mathrm{C}=\mathrm{a}$ mért érték és a részérték szor zata; A, B, C állandó összege = az egyén DAI értéke 
2. táblázat | DAI-érték szerinti osztályozás

\begin{tabular}{|c|c|c|}
\hline DAI-érték & A kezelés szükségessége & Súlyossági fok \\
\hline$\leq 25$ & $\begin{array}{l}\text { Nem vagy kismértékben } \\
\text { kell }\end{array}$ & $\begin{array}{l}\text { Normális okklúzió vagy } \\
\text { enyhe eltérés }\end{array}$ \\
\hline $26-30$ & Szükséges & Harapási rendellenesség \\
\hline $31-35$ & Fokozottan szükséges & Súlyos rendellenesség \\
\hline$\geq 36$ & Elengedhetetlen/kötelező & $\begin{array}{l}\text { Nagyon súlyos rendelle- } \\
\text { nesség }\end{array}$ \\
\hline
\end{tabular}

rangkorrelációs együtthatót pedig a vizsgált esetek életkora és DAI-mutatója közötti összefüggésre számoltuk (statisztikailag szignifikánsnak a $\mathrm{p} \leq 0,05$ értékeket tekintettük). Egyszempontos varianciaanalízis (ANOVA) érdekében az életkort, a nemet és a kezelési szükségszerüséget független változónak tekintettük, és a statisztikai elemzés során ekképp használtuk őket.

\section{Eredmények}

A vizsgálatnak alávetett 64 eset közül 23 (36\%) férfi és 41 (64\%) nő volt, az átlagéletkor 30,48 év volt, és 16-55 év között mozgott. A DAI-mutató átlagértéke 38 (1879 között) volt, ami arra enged következtetni, hogy az esetek több mint $2 / 5$-e esetén a fogszabályozás kötelező. Az esetek 13,33\%-a nem igényel szakorvosi ellátást, 24,44\%-ban a fogszabályozás szükséges, míg a fennmaradó $62,22 \%$-ban elengedhetetlen, illetve fokozottan szükséges (1. ábra).

A 2. és a 3. ábrán eseteink nem és életkor szerinti eloszlását elemeztük.

A DAI-mutató szerinti felosztásban, a 25-nél kisebb (a kezelés nem szükséges), illetve a 25-nél nagyobb (a kezelés különböző mértékben szükséges) eseteket külön értékelve kimutatható, hogy csak eseteink közel 14\%-ában találtunk a normálishoz közel álló okklúziót, míg több mint 86\%-ukban a fogszabályozás szükségesnek bizonyult.

A khí-négyzet-próba elvégzése után nem találtunk statisztikailag szignifikáns eltéréseket sem a nemek ( $\mathrm{p}=$ $0,677)$, sem az életkor ( $p=0,292)$ vagy a kezelési szükségszerüség $(\mathrm{p}=0,067)$ szerinti eloszlásban.

\section{Megbeszélés}

Megjelenésünk, egy szép és természetes mosoly pszichoszociális szempontból meghatározza közérzetünket. Számtalan tanulmány tárgyát képezi mind a mai napig a fogazati rendellenességek és az életminőség közötti öszszefüggések értékelése [7-9].

Az általunk használt DAI-mutató összefüggést képes megállapítani egy fogazati vagy harapási rendellenesség és ennek kezelési szükséglete között; az alkalmazott módszer gyors, egyszerú, megbízható és értékelhető. Intraorális felmérésre ad lehetőséget, az esztétika és a funkció együttes felmérését végzi el [9] anélkül, hogy

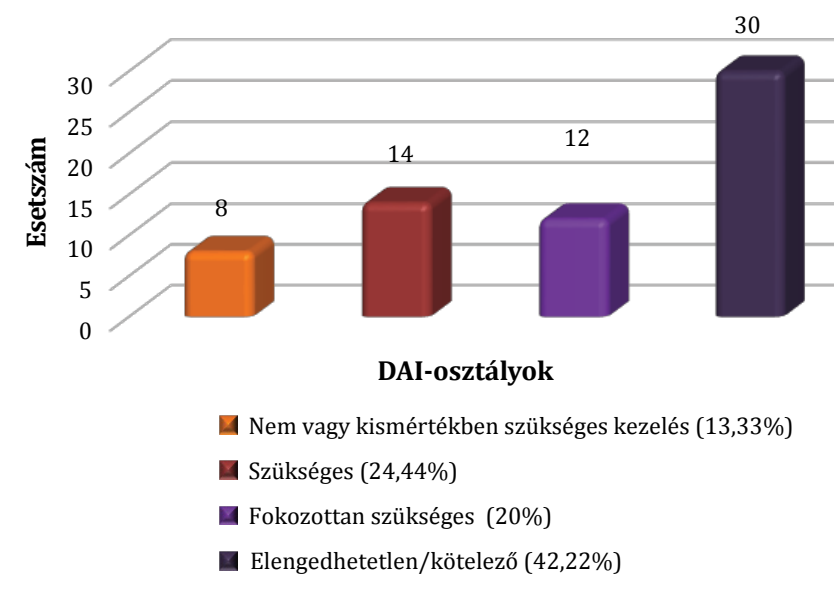

1. ábra | A vizsgált csoport DAI-osztályok szerinti eloszlása

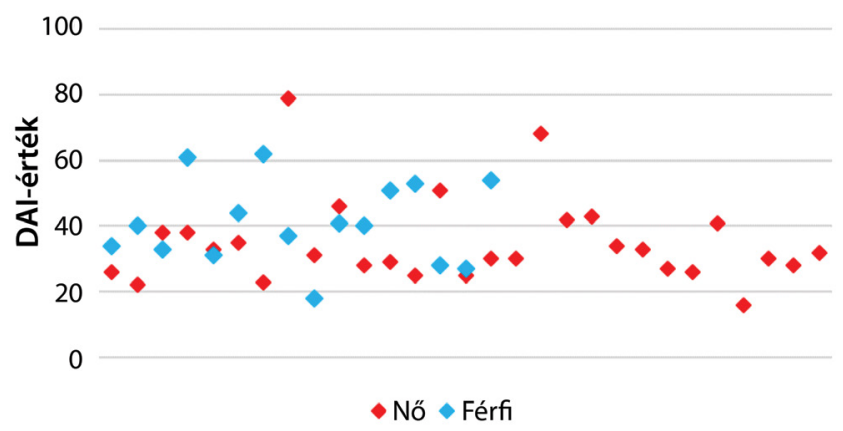

2. ábra $\mid$ A nemek DAI-érték szerinti eloszlása

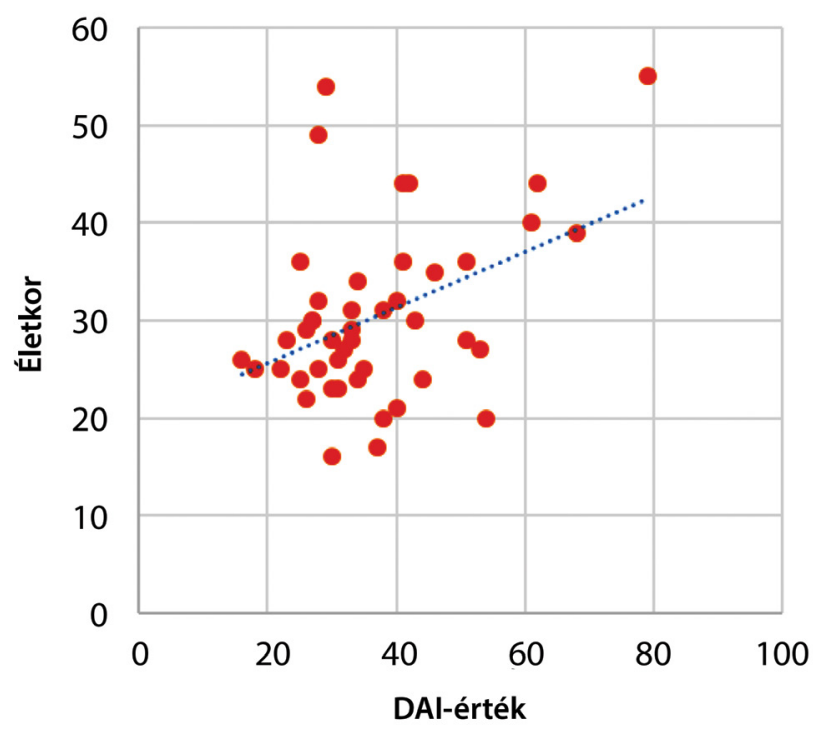

3. ábra |Az életkor és a DAI-érték függvénye

imagisztikai kivizsgálásra lenne szükség [5]. Habár egy ortodonciában használt mutatóról van szó, a regressziós egyenlet alkalmazásával az egyén DAI-mutatója [1] kifejezi a közvélemény esztétikával szemben támasztott igényét [10], miközben az okklúzió jellemvonásaira tá- 
maszkodva meghatározza az adott rendellenesség súlyossági fokát [2].

A mutatót alkotók által felhasznált tíz okklúziós jellemző azonban kicsit leszúkítheti a vizsgálandó és a tulajdonképpeni kezelés szükségességét meghatározó tényezők sorát. A szkeletális eltérések, a funkcionális zavarok, a nagyobb méretű nyelv, a mélyharapás vagy a hátulsó (tehát nem látható) nyitott harapás, a posterior (szemfog-kisőrlő) régió torlódásai, a kamuflált vegyes fogazati torlódás, a szám feletti fogak vagy a rotációk nem szerepelnek az egyéni mutatót meghatározó jellemvonások között. Ennek ellenére a DAI-mutató megfelel egy szürővizsgálat feltételeinek, és egyértelműen arra enged következtetni, hogy a kezelendőnek vélt esetek további, komplex ortodonciai kivizsgálása kötelező.

Az általunk talált 38-as DAI-átlagérték (az értékek 18-79 között mozogtak) arra engedett következtetni, hogy a vizsgált személyek legnagyobb része $(42,22 \%)$ nagyon súlyos fogazati rendellenességben szenved, és semmiképp nem kerülhetik el a fogszabályozást. Eseteink 13,33\%-ában tudjuk azt kijelenteni, hogy az észlelt eltérés kisfokú, vagy akár hiányzik, és a kezelés nem szükséges. Eseteink majdnem negyedében a rendellenesség nyilvánvaló, a fennmaradó $20 \%$-ban pedig súlyos, és a kezelés fokozottan szükséges.

A DAI-mutatók segítségével számos tanulmány határozta meg a rendellenességek súlyossági fokát és kezelésük szükségességét [11-13]. A P. M. Maumela [11] (2010, Dél-Afrika) tanulmánya során kapott eloszlások szerint a 120 vizsgált gyerek és felnőtt (életkor 10-45 év) 19,1\%-a szabadul csak meg a fogszabályozástól, 80\%uk nem tudja ezt elkerülni. Ez utóbbiak közül 41,7\%ban a tapasztalt rendellenesség rendkívül súlyosnak bizonyult, 21,7\%-ban volt súlyos, és 17,5\%-ban maradandónak bizonyult. Ezen tanulmány során számolt DAI-mutató átlagértéke megközelítette az általunk számolt értéket: $35,2 \pm 10,3[11]$

Onyeaso és BeGole [12] (2006, Észak-Amerika) 100 egyén (életkor 10-52 év) kezelés előtti tanulmányi mintáját vizsgálva azt találta, hogy az esetek 85\%-ában a rendellenesség eltérő súlyossági foka ellenére a fogszabályozás szükséges, míg 47\%-ban annyira súlyos eseteket találtak, hogy a kezelés kötelezőnek bizonyult [12].

A spanyolországi Valencia régióban végzett tanulmány egy 35-44 év közötti felnőttekből álló reprezentatív csoportot vizsgálva azt találta, hogy az esetek $68,7 \%$-a nem igényel kezelést, és 28,3 DAI-átlagérték mellett a terápia csak az esetek 31,3\%-ánál szükséges [13].

Goyal és Mubigana Kigali (Ruanda) térségében öt éven át - 2008-2013 között - 170 gyereken és fiatal felnőtten (életkor 11-35 év) végzett tanulmányuk alapján megállapították, hogy mindössze $11 \%$-uknál mellőzhető a fogszabályozás, 89\%-uknál viszont valamilyen beavatkozásra szülkség van [14]. A kezelést igénylő esetek 23\%-ában az észlelt rendellenesség súlyosnak, 51\%-ában pedig rendkívül súlyosnak bizonyultak, a számolt átlagos DAI-mutató pedig 37 volt $[14,15]$.
Mindezen tanulmányokkal való összehasonlítás alapján kijelenthetjük, hogy az általunk kapott DAI-átlagérték (38) magasabb volt, mint az említett tanulmányok során kapott értékek (Dél-Afrika 35,2 [11], Spanyolország 28,3 [13], Ruanda 37 [14]), miközben a kiválasztott tanulmányok módszertana megegyezett az általunk alkalmazottal, a vizsgált egyének életkor szerinti csoportosítása úgyszintén. Az eltérő értékek magyarázata a közösségi fogászati ellátás finanszírozására fordított összegekben is keresendő, hiszen köztudott, hogy ez országonként különbözik [16].

\section{Következtetés}

1. Az egyéni DAI-mutató alapján az általunk vizsgált 64 személy több mint $40 \%$-ának esetében a fogszabályozás elengedhetetlen.

2. Újabb, az eredeti DAI-mutató meghatározásában nem szereplő okklúziós jellemzők bevonása esetén a kezelésre vonatkozó döntés változhat.

3. Nem találtunk statisztikailag szignifikáns eltérést a vizsgált 64 eset nem, életkor és kezelési szükséglet szerinti értékelésében.

Anyagi támogatás: A közlemény megírása, illetve a hozzá tartozó kutatómunka anyagi támogatásban nem részesült.

Szerzői munkamegosztás: S. I. P.: A tanulmányba bevont esetek szelekciója, anyag és módszer - távröntgenek és mérések értékelése. M. I. K.: A közlemény végleges szerkesztése. Cs. R.: A kérdőívek értékelése, az adatok öszszegzése. M. P.: A közlemény szerkesztése. C. M.: Az adatok statisztikai feldolgozása és értékelése. D. C. B.: A közlemény végleges szerkesztése. A cikk végleges változatát minden szerző elolvasta, véleményezte és jóváhagyta.

Érdekeltségek: A szerzőknek nincsenek érdekeltségeik.

\section{Irodalom}

[1] Borzabadi-Farahani A. An insight into four orthodontic treat ment need indices. Prog Orthod. 2011; 12: 132-142.

[2] Almeida AB, Leite IC, Melgaço CA, et al. Dissatisfaction with dentofacial appearance and the normative need for orthodontic treatment: determinant factors. Dental Press J Orthod. 2014; 19: 120-126

[3] Shelton AT, Hobson RS, Slater D. A preliminary evaluation of pre-treatment hypodontia patients using the Dental Aesthetic Index. How does it compare with other commonly used indices? Eur J Orthod. 2008; 30: 244-248.

[4] World Health Organization. Oral health surveys: basic methods. 4th edn. WHO, Geneva. 1997.

[5] Cons NC, Jenny J, Kohout FJ. DAI: The Dental Aesthetic Index. College of Dentistry, Iowa, 1986.

[6] Jenny J, Cons NC. Establishing malocclusion severity levels on the Dental Aesthetic Index (DAI) scale. Aust Dent J. 1996; 41: $43-46$. 
[7] Liu Z, McGrath C, Hagg U. Associations between orthodontic treatment need and oral health-related quality of life among young adults: does it depend on how you assess them? Commun Dent Oral Epidemiol. 2011; 39: 137-144.

[8] Masood Y, Masood M, Zainul NN, et al. Impact of malocclusion on oral health related quality of life in young people. Health Qual Life Outcomes 2013; 26: 11-25.

[9] Manjith CM, Karnam SK, Manglam S, et al. Oral Health-Related Quality of Life (OHQoL) among adolescents seeking orthodontic treatment. J Contemp Dent Pract. 2012; 13: 294-298.

[10] Akshay G. Orthodontic treatment needs of children living in orphanage according to the Dental Aesthetic Index (DAI). Sch J Dent Sci. 2015; 2: 49-53.

[11] Maumela PM. Application of the dental aesthetic index in the prioritization of orthodontic service needs. Research Dissertation. Submitted in fulfilment of the requirements for the degree of Master of Dentistry in Orthodontics in the Department of Orthodontics (School of Oral Health Sciences). University of Limpopo, 2010.

[12] Onyeaso CO, BeGole C. Orthodontic treatment need in an accredited graduate orthodontic center in North America: a pilot study. EAJ Contemp Dent Pract. 2006; 7: 87-94.
[13] Bellot-Arcís C, Mantiel-Campany JM, Manzanera-Pastor D, et al. Orthodontic treatment need in a Spanish young adult population. Med Oral Patol Oral Cir Bucal 2012; 17: 638-643.

[14] Goyal S, Muhigana A. Assessment of malocclusion severity levels and orthodontic treatment needs using the Dental Aesthetic Index (DAI): A retrospective study. RMJ 2013; 70: 20-27.

[15] Fábián G, Gábris K, Tarján I. Pediatric dentistry, orthodontics and dentofacial orthopedics. [Gyermekfogászat, fogszabályozás és állcsont-ortopédia.] Semmelweis Kiadó, Budapest, 2015. [Hungarian]

[16] Marada Gy, Nagy A, Sebestyén A, et al. Reimbursement of public dental care in Germany, the United Kingdom, Hungary and Poland. [A fogászati ellátás finanszírozása Németországban, az Egyesült Királyságban, Magyarországon és Lengyelországban.] Orv Hetil. 2016, 157: 547-553. [Hungarian]

(Mártha Krisztina dr., Marosvásárbely, Gh. Marinescu u. 38., 540139, Románia e-mail: marthakriszti@yahoo.com)

\section{Pályázati felhívás}

Professzor Dr. Fehér János munkássága, szakmai és erkölcsi hagyatéka páratlan és maradandó az orvostudományban. Ezért a Semmelweis Egyetem Általános Orvostudományi Kar II. sz. Belgyógyászati Klinika volt igazgatója, „A hepatológiai szabad gyökös és immunológiai vonatkozásai" címü program vezetőjének, az Orvosi Hetilap főszerkesztőjének emlékére Alapítvány létesült. Az alapítványt a Fővárosi Bíróság 2011. március 7-én 11.335. sorszám alatt nyilvántartásba vette.

Dr. Fehér János Emlékére Alapítvány fő célja: a belgyógyászat, különösen a hepatológia szabad gyökös és immunológiai vonatkozásai témakörök kutatásának fejlesztése, támogatása, illetve ösztönzése oly módon, hogy a fiatal egyetemi oktatók és hallgatók az alapítvány kamatából részesüljenek. Az alapitvány célja olyan orvosok, PhD-hallgatók díjazása, akik kiemelkedő tudományos munkát végeznek és eredményeiket az Orvosi Hetilapban publikálják.

A dolgozatot „Dr. Fehér János pályázat” megjelölésével kell benyújtani.

A pályázatot 2018. április 15-ig lehet beküldeni a Kuratórium elnökének (Dr. Hagymási Krisztina) vagy titkárának (Dr. Lengyel Gabriella) - Semmelweis Egyetem, II. sz. Belgyógyászati Klinika, 1088 Budapest, Szentkirályi u. 46. címre.

A pályázathoz mellékelni kell a pályázó önéletrajzát és a dolgozatot.

A dijjak odaítéléséről a kuratórium dönt. A dij átadására a Markusovszky ünnepségen kerül sor. Az ünnepségen a nyertes pályázó maximum 5-10 perces előadásban foglalja össze az eredményeit. 